\title{
Varieties of populist constitutionalism: The transnational dimension
}

\author{
Paul Blokker*
}

(Received 31 December 2018; accepted 15 January 2019)

\begin{abstract}
Populist constitutionalism is an increasingly discussed topic, but so far the analysis of the interrelation between populism and constitutionalism lacks a more systematic and comparative approach, able to bring out significant variety. Most of the recent literature on the phenomenon focuses on (right-wing) populism as a threat to constitutional democracy. This Article sets out to contribute to a more comparative and comprehensive discussion of the relation between varieties of populism-situated on a continuum from left- to right-wing, but also from national to transnational-with varieties of constitutional projects. The objective of this Article is threefold. First, I argue that it is problematic to consider legal constitutionalism as exhausting the possibilities of constitutionalism. Second, if populism is reduced to right-wing projects and as an unequivocal threat to liberal democracy, it becomes difficult to distinguish between dissimilar manifestations of populist projects, in particular regarding constituent politics. Third, while hardly any attention has been paid to constitutionalism and populist claims on the transnational level, in the European context, transnational forms of populism and constituent politics manifest themselves frequently, articulating an incisive critique on the European constitutional and political status quo, and contributing to a re-imagination and democratization of the European constitutional reality.
\end{abstract}

Populist constitutionalism is an increasingly discussed topic, but the interrelation between populism and constitutionalism still lacks a more systematic and comparative analysis. Much of the emerging literature on the phenomenon focuses on (right-wing) populism as a threat to constitutional democracy. ${ }^{1}$ As such, a comparative and theoretical treatment of populist constitutionalism, which is able to deal with the different manifestations of the phenomenon, is as yet absent.

In contrast to a relatively narrow focus on right-wing populism and its relation to constitutional change, this Article sets out to contribute to a more comparative and comprehensive discussion of the relation between varieties of populism-situated on a continuum from left- to right-wing, but also from national to transnational-with varieties of constitutional projects.

${ }^{*}$ Paul Blokker is associate professor at the University of Bologna and research fellow at the Charles University in Prague. The author acknowledges funding for the research project Transnational populism and European democracy (TRAPpED) of the Czech Science Foundation (Grantová agentura České republiky) (Standard Project 18-25924S) as well as a Jean Monnet Chair in European Political Sociology, funded by the European Commission (575140). Email: paulus.blokker@unibo.it

${ }^{1}$ See, e.g., Gábor Halmai, Is There Such Thing as 'Populist Constitutionalism'? The Case of Hungary, 2 FudAN J. HUMAN. \& Soc. SCI., 1-17 (2017); Cas Mudde, Are Populists Friends or Foes of Constitutionalism?, THE FOUND. FOR L., JUST. AND SOC'Y Pol'y Brief (2013); Jan-Werner Müller, What Is Populism? (2016); Jan-Werner Müller, Populism and Constitutionalism, in The Oxford Handbook of Populism (Cristóbal Rovira Kaltwasser et al. eds., 2018); Kim Lane Scheppele, Autocratic Legalism, 85 U. CHI. L. REV. 545 (2018). For a rich comparative approach, which however stresses the idea that populism is a threat to liberal democracy see David Landau, Populist Constitutions, 85 U. CHI. L. Rev. 521 (2018).

(C) 2019 The Author. Published by Cambridge University Press on behalf of the German Law Journal. This is an Open Access article, distributed under the terms of the Creative Commons Attribution licence (http://creativecommons.org/licenses/by/4.0/), which permits unrestricted re-use, distribution, and reproduction in any medium, provided the original work is properly cited. 
The general approach towards populism argues that it displays a friend-enemy logic in its political mobilization of ordinary citizens, engages in the construction of a unified people, and criticizes the liberal-democratic status quo in the people's name. ${ }^{2}$ Liberal democracy, according to populists, is inadequate in promoting popular sovereignty. This general set of observations is accurate, I believe, but it leaves out one highly significant aspect: the crucial role of constituent power in populist projects. As recently stressed by Kolja Möller, studies on populism tend to overlook that the "invocation of 'the people' is not only a matter of bolstering mere political discourse, but of constitutional politics addressing the higher-ranking dimension of the legal and political community, the distribution of powers, and the overall design of rule-making and application." ${ }^{3}$ As Möller rightly claims, "[p]opulism does not only refer to certain policy issues, but invokes "the people" as constituent power on which the political community relies." Different populisms draw on the "multi-faceted character of foundational peoplehood" and in this, "populists do not rely on a societal foundational force which checks and authorizes public institutions, but in fact can also turn the constitutional structure or the state against the 'elites,' supranational agreements, or economic powers."

The argument here is that the populism-constitutionalism nexus hinges on the populist prioritization of constituent politics, which renders this nexus as essential for the populist political project, a point largely ignored by mainstream political science studies in populism. The way constituent politics is addressed, and in turn, the manner in which it addresses the existing constitutional status quo depends profoundly on the distinctive constitutional imagination of the populist force at hand. A key obstacle to be dealt with by all populist projects is that of legal constitutional institutions. The populist critique perceives such institutions as hindering actual and meaningful popular sovereignty. The way populists imagine, however, to correct, utilize, or overcome such institutions differs importantly between populist movements.

This Article has three arguments. First, that there is a danger in conflating modern constitutionalism with legal constitutionalism, and understanding it as exhausting the possibilities of constitutionalism. This also means that potential deficiencies in legal constitutionalism which might lead to critique and somehow provide fertile ground for populist reactions are ignored. Second, if populism is reduced to a threat to constitutionalism, as appears prominent in much of the recent literature, it becomes difficult to distinguish between forms of populist claims on constitutions (including inclusionary and democratic claims) and different engagements with constitutions and constituent politics. Third, while hardly any attention has been paid to constitutionalism and populist claims on the transnational level, in the European context, transnational forms of populism and constituent politics manifest themselves frequently, articulating an incisive critique on the European constitutional and political status quo, and contributing to a re-imagination and democratization of the European constitutional reality. One significant example of this are the constitutional claims of the Democracy in Europe Movement (DiEM25).

\section{A. Legal constitutionalism and its alternatives}

A crucial starting point of current manifestations of populism and constituent politics needs to be the post-1945 emergence of a distinctive constitutional imagination. ${ }^{6}$ The post-war paradigm of

\footnotetext{
${ }^{2} C f$. Jan-Werner Müller, What Is Populism? (2016); Nadia Urbinati, Democracy disfigured: Opinion, Truth, and THE PEOPLe (2014).

${ }^{3}$ Jan-Werner Müller, Populism and Constitutionalism, in THE OxFord HANDBOOK OF PopUlism 1, 17 (Cristóbal Rovira Kaltwasser et al. eds., 2018).

${ }^{4} I d$.; Cf. Luigi Corrias, Populism in a Constitutional Key: Constituent Power, Popular Sovereignty and Constitutional Identity, 12 Eur. Const. L. Rev. 6 (2016).

${ }^{5}$ Müller, supra note 3 , at $17-18$.

${ }^{6}$ Cf. Tom Ginsburg et al., The Coming Demise of Liberal Constitutionalism, 85 U. CHI. L. Rev. 239 (2018); Paul Blokker, Populism as a Constitutional Project, 17 INT'L J. ConsT. L. (forthcoming 2019); Paul Blokker, The Imaginary Constitution of Constitutions, 3 Soc. IMAGINARIES 167 (2017).
} 
constitutionalism is grounded in a distinctive constitutional imaginary, strongly emphasizing aspects of stability and order. ${ }^{7}$ This paradigm, identified here as having crystallized into the institutional blueprint of "legal constitutionalism," is what deeply informs the global constitutional landscape as well as the constitutional visions of many constitutional scholars. It is also this distinctive idea of constitutionalism from which the current academic interest in populism departs, and it explains constitutional scholars' contemporary intellectual distress.

It is crucial to focus on this paradigm, but not so much because it is the only available version of constitutionalism. Rather, because this form of constitutionalism-which has particularly developed strongly in the aftermath of the Second World War-has become the main culprit for populists of either left or right-wing nature. As Mark Tushnet has recently argued, ${ }^{8}$ different varieties of populism take positions against liberalism and cosmopolitanism, understood as institutional projects consisting of distinctive, legalistic interpretations of liberalism, expressed inter alia in rigid constitutions, judicial independence, and strong courts. ${ }^{9}$ It is, in my view, highly important to approach this legal-constitutional paradigm in a reflexive and analytically curious and critical manner, and to put it in the context of a historically emerged and competing range of constitutionalisms, not least to get a more precise idea of how and why populists take issue with the legalconstitutional idea and practice, and what exactly informs their alternative constitutional projects. ${ }^{10}$

In much of the recent literature, populism is understood as a political manifestation that negates-or at the very minimum threatens-constitutional democracy. As Jan-Werner Müller has recently put it, "populism is inherently hostile to the mechanisms, and ultimately, the values commonly associated with constitutionalism: Constraints on the will of the majority, checks and balances, protections for minorities, and even fundamental rights." ${ }^{11}$ Populists are seen as impatient with procedures and institutions, and as loath of intermediary bodies, as they prefer unmediated relations between the populist ruler and the people. Populists prefer direct "natural" or "pure" forms of politics, in contrast to indirect and artificial ones. ${ }^{12}$ A relatively clear example of the description of the antithetical relation that most constitutional scholars detect when discussing populism can be found in Sajo and Uitz's recent book on legal constitutionalism:

Constitutionalism stands for minorities (at least in the minimum sense that they have the right or legal possibility to be part of the majority, or become the majority). The populist stands for the unity of the people and those who are 'outside' (the others or 'them') do not count. This helpful division is often made on xenophobic grounds: the others are those who do not share the (imaginary) national identity based on immutable characteristics. Such constitutional populism relies on identity politics. ${ }^{13}$

\footnotetext{
${ }^{7} \mathrm{Cf}$. TAmas GyöRfi, Against the new COnstitutionalism (Edward Elgar 2016).

${ }^{8}$ Mark Tushnet, Comparing Right-Wing and Left-Wing Populism, in Constitutional Democracy IN Crisis? 639 (Mark Graber et al. ed., 2018).

${ }^{9} \mathrm{Id}$.

${ }^{10}$ Recent attempts to criticize, or actually put the blame on (!) pluralistic approaches to constitutionalism, such as Daniel Kelemen \& Laurent Pech, Why autocrats love constitutional identity and constitutional pluralism. Lessons from Hungary and Poland 2018 (RECONNECT Working Paper No. 2, September 2018) apparently in favor of some form of untouchable constitutional orthodoxy, are unfortunate. Kelemen and Pech conflate scholarly reflexivity, analytical and conceptual openness, and critical scientific endeavor, on one hand, with dubious constitutional practices by populist political forces, on the other. Zoran Oklopcic's points on "anti-populists conjurers" and the ideological nature of liberal constitutionalism, as suggested in his forthcoming contribution to GLJ, is articulating very aptly my concerns here, Zoran Oklopcic, Imagined ideologies: Populist Incarnations, Liberalist Projections, and the Horizons of Constitutionalism, GERMAN L. J. (forthcoming); see also Michal Ovádek, Constitutional Pluralism between Normative Theory and Empirical Fact, VerfBlog (Oct. 23, 2018), https:// verfassungsblog.de/constitutional-pluralism-between-normative-theory-and-empirical-fact/.

${ }^{11}$ Müller, supra note 2, at 68; $C f$. Nadia Urbinati, Democracy disfigured: Opinion, Truth, and the People (2014).

${ }^{12}$ Nadia Urbinati, Democracy and Populism, 5 Constellations 110, 111 (1998).

${ }^{13}$ András Sajó \& Renáta Uitz, The Constitution of Freedom: An Introduction to Legal Constitutionalism 53 (2017).
} 
Sajo and Uitz rightly discuss populism in connection to a range of contemporary challenges to constitutionalism - which includes not only right-wing, nationalist political forces-but a whole range of radical challenges to the legal-constitutional idea:

Contemporary constitutionalism is confronted by a good number of threats. There is an arrogant intellectual-political dislike of constitutionalism, among other things because of its intimate historical association with classic (nineteenth-century) liberalism, as liberalism became a major target of conservative, leftist, and various radical (communist, fascist) political movements. These movements stand for a pre-ordained (past or utopian) social order. Whenever they were able to shape constitutions, constitutional practices, and constitutional law, this was detrimental to fundamental principles of constitutionalism. In these ideologies limiting power in the name of the rule of law is unsustainable, costly, and inefficient, as it deprives us of security. The Nation needs unity: all these forces plan to realize their vision by a unilateral control over government. ${ }^{14}$

But the citation also reveals a certain frustration with recalcitrant forces that do not want to learn the lesson of "true" constitutionalism. In this, there is a certain unwillingness to engage with a more self-reflexive, and perhaps even, pluralistic idea of constitutionalism. The latter can be understood as different possible institutionalizations of the constitutional idea, grounded in distinctive prioritized higher principles. In other words, it might be the case that the legal constitutionalists entertain a certain arrogance too. ${ }^{15}$ Mind that the call for a self-reflexive and pluralistic approach is not an invitation for an anything goes type of constitutionalism. It is rather a reminder, in a historical-sociological sense, that constitutions perform different functionslimitative, regulatory, symbolic, integrative, and emancipatory-and tend to manifest themselves in different guises in different societies; in a political sense, that the political nature of constitutions means that an endurable consensus on fundamental norms is a chimera.

One upshot of such a self-reflexive pluralistic approach is that there is a risk-as many scholars have indeed pointed out - that constitutional orders overemphasize one set of dimensions-let us say order, legal certainty, and the rule of law) over others (for instance, social equality, emancipation, and popular participation. The debate on legal versus political constitutionalism is a case in point. Despite the urgency of the very real threat against liberal-constitutional democracy in contemporary times, it might be equally urgent to detect and reveal specific in-built tensions in the postwar legal-constitutional project. Such insights might shed light on the thrust and mobilizing force of the current wave of populist counter-constitutionalism and-rather than making us repropose an unlikely return to the status quo ex ante-may help us to think in more fruitful and innovative ways about constitutional democracy. As Mark Tushnet has recently argued, "treating efforts to transform the courts as a strong point-'assaults on judicial independence'-against populism is a defense of the failed status quo, not a politically neutral defense of a central component of every good constitution."16

So let us start with a stylized, but critical characterization of what I deem the predominant view of constitutionalism to be, one that according to many needs to be defended against, amongst others, the populist challenge. Critical comparative analyses of the post-WWII rise of constitutionalism indicate a distinctive model of constitutionalism, ${ }^{17}$ which is not as universal

\footnotetext{
${ }^{14} I d$. at $52-53$ (emphasis added).

${ }^{15}$ In some instances, the arrogance and resulting intellectual closure is blatant, as in recent debates on constitutional pluralism.

${ }^{16}$ Tushnet, supra note 8 , at 644 .

${ }^{17}$ John Ferejohn, Judicializing Politics, Politicizing Law, 65 L. \& CONTEMP. PROBS., 41 (2002); Ran Hirschl, The Political Origins of the New Constitutionalism, 11 Ind. J. OF Global Legal Stud. 71 (2004); Heinz Klug, Constituting Democracy: Law, Globalism and South Africa's Political Reconstruction (Cambridge University Press 2000); Alec Stone Sweet, Constitutions and Judicial Power, in Comparative Politics 217 (D. Caramani ed., 2008); Alec Stone
} 
as it is frequently claimed, but rather forms a specific answer to a distinctive set of dramatic challenges that Europe faced in the wake of the Second World War, challenges that later were deemed not dissimilar to those of post-authoritarian and post-communist societies. The postwar trend-certainly not limited to Europe-is one of an indeed globally, visible convergence around a relatively uniform, legal-constitutional model. ${ }^{18}$ Legal constitutionalism tends to be identified according to, among others, the following generic features. First, a modern constitution is regarded a structure of law that is in important ways separate from its subjects. Whereas the modern constitution is ultimately dependent on the people for its legitimation, once constituted, it becomes a relatively autonomous set of meta-norms and rules that constitutes social and political interaction. James Tully speaks about this relative autonomy or externality as the "formality" of modern constitutions. ${ }^{19}$ Second, one of the essential ideas behind the constitution is to channel and express popular sovereignty. The act of the constitution transfers this sovereignty from the pouvoir constituant (the power of the multitude or the 'people') to the pouvoir constituée (the authoritative institutions created), which in the postwar legal-constitutional narrative means prioritizing judicial institutions. Many of the postwar constitutions involve a re-positioning in the classical relation between the branches of government, and the growing force of the judiciary means, in the formation of constitutions, that the classical functions of the constituent power are diminished in scope, and, after their formation, that the formal authority of legislatures is weakened. Most constitutional orders ascribe a high degree of importance to the judicial branch-especially to Constitutional Courts or Supreme Courts-which acquire responsibilities for constitutional review of statutes and for ensuring conformity between domestic and international law. Third, modern constitutions are understood as coherent and noncontradictory, contractual structures, in which "constitutional essentials are unambiguously settled and made binding into the future." ${ }^{20}$ Fourth, while most of the dimensions noted above invoke a pre-political, limitative, and foundational perception of constitutions, constitutions also provide for a positive democratic dimension. This includes positive civil and political rights which enable citizens and political actors to act set their own rules, but within the limits set by the very same constitution.

The emergence of a universal legal-constitutional model of society is then equally related to a tendency towards judicialization in modern societies, which includes a "profound shift of power away from legislatures and toward courts and other legal institutions around the world." 21 Judicialization further refers to a growing importance of legal norms in social interaction-not least in the form of human rights - shifting political demands and claims away from representative and participatory democratic institutions to the legal arena.

In particular, in the last few decades the legal-constitutional paradigm has gained dominance in the global constitutional landscape, but is not without contestation. In recent times, a number of competing constitutional narratives have become visible, and are explicitly formulated against some of the key tenets of legal constitutionalism. Below I will engage with three of such competing narratives: (I) political constitutionalism; (II) communitarian constitutionalism; and (III) democratic constitutionalism.

\footnotetext{
Sweet, Constitutionalism, Legal Pluralism and International Regimes, 16 IND. J. OF Global LeGal StUd. 621 (2009); Stephen Gill \& A.Claire Cutler eds., NEW CONSTITUTIONALISM AND WORLD ORDER (2014).

${ }^{18}$ Heinz Klug, Constituting Democracy: Law, Globalism and South Africa's Political Reconstruction (Cambridge University Press 2000).

${ }^{19}$ James Tully, A New Kind of Europe?: Democratic Integration in the European Union, 10 CritiCAL Rev. INT'L SOC. \& POL. PHIL. 71 (2007).

${ }^{20}$ Simone Chambers, Contract or Conversation? Theoretical Lessons from the Canadian Constitutional Crisis, 26 PoL. \& SoC'y 143 (1998).

${ }^{21}$ Ferejohn, supra note 17 , at 41.
} 


\section{Political constitutionalism}

Until fairly recently, the legal constitutional model appeared to be predominantly challenged-on a theoretical plane-by political and constitutional theorists endorsing an alternative model: political constitutionalism. ${ }^{22}$ A key point of contention regards the role of apex courts, and more particularly, the role of judicial review of, most prominently, legislative acts. ${ }^{23}$ As Amhlaigh states, the

Most popular front of contestation between political and legal constitutionalism has been with regard to the question of whether courts or legislatures should have ultimate decisionmaking authority on the identification, interpretation, and application of the fundamental values, usually expressed as fundamental rights, of a particular legal order or constitutional settlement. $^{24}$

What is of great significance in this debate is that it sensitizes constitutional observers to the fact that constitutionalism is neither reducible to a neat, ideologically neutral, and theoretically uncontested ideal, nor to a distinct set of constitutional institutions in practice. In other words, constitutionalism is more pluralistic both on the theoretical plane-different, sometimes contrasting, ideas are put forward-and on the empirical, societal level-different institutionalizations of the idea exist.

The political-constitutionalist conception challenges the legal-constitutional idea by taking a rather different view of the role and substance of the constitution, and its relation to democratic politics. The constitution is not seen as grounded in an entrenched set of fundamental principles - jealously guarded by apex courts_-but rather as the framework for the articulation of and deliberation over conceptions of self-government and the common good. The relation between democracy and constitutionalism in political constitutionalism is based not on the need for depoliticized pre-commitments or extra-political guarantees and the idea of superior judgmental capacity (of judicial experts). Rather, the emphasis is on the idea of political equality and a thrust towards the inclusion of a wide range of people's judgments, understood as best achieved by means of parliamentarism. ${ }^{25}$

The political view of the constitution (re-)opens a door for the influence of politics on the law, in that it emphasizes the negotiation of differences and a continuous quest for mutually agreeable conditions. It is, in this, however, endorsing a return to the status quo ex ante, that is, parliamentcentered constitutional democracy. ${ }^{26}$ Political constitutionalists hold that it is the legislature that is ultimately best able to represent the irreducible diversity of viewpoints in society. Indeed,

So long as a system of equal votes, majority rule and party competition-however interpreted-offers a plausible system for giving citizens an equal say in the ways collective arrangements are organized-including those of the democratic process-then a selfconstituting democratic constitution that avoids dominating through arbitrary rule will have been secured. ${ }^{27}$

Existing representative arrangements are thus preferred also as means of constitution-making, while extra-institutional actors and politics are looked at with a certain skepticism:

\footnotetext{
${ }^{22} \mathrm{Cf}$. Richard Bellamy, Political Constitutionalism: A Republican Defence of the Constitutionality of Democracy (Cambridge University Press 2007); Jeremy Waldron, LaW and Disagreement (1999).

${ }^{23}$ Cormac Mac Amhlaigh, Putting Political Constitutionalism in its Place, 14 InT'L J. Const. L. 175 (2016).

${ }^{24} \mathrm{Id}$. at 176.

${ }^{25}$ See Marco Goldoni, Two Internal Critiques of Political Constitutionalism, 10 INT'L J. ConsT. L. 926 (2012).

${ }^{26}$ Marco Goldoni, Political Constitutionalism and the Question of Constitution-Making, 27 RATIO JURIS 387 (2014).

${ }^{27}$ Bellamy, supra note 22 , at $220-21$.
} 
Constitutions are structuring, enabling devices in that "it is a matter of what a constitution affirmatively makes possible out of what would otherwise be the loose and lurching and dangerous politics of the streets." 28

Political constitutionalism's main critique of legal constitutionalism is its insistence on norm entrenchment and judicial review. The argument is—rightly from a democratic viewpoint - that constitutional arrangements should not be imposed on a democratic society, but should rather be the result of reflections of 'the people whose society is to be governed by these arrangements. ${ }^{29}$ Constitutions institutionalize "legislatures, large institutions, manned (peopled) in a certain way and invested with public authority so that they can act credibly in the name of us all." 30

The critique of political constitutionalism on the legal-constitutional hegemony points to tensions in the legal-constitutional construct and provides an important re-opening of the social imagination of what constitutionalism is and what it is for. This re-imagining remains not confined to the theoretical sphere, but is equally manifest in claims of political forces-not least populist ones. A highly relevant example is that of the UK-where a form of legal or judicial constitutionalism has been gaining ground since the 1980s — not least in the form of the adoption of the Human Rights Act in 1998. This rise of judicial constitutionalism has however been an object of great concern, and its contestation is - in important ways-part of the current Brexit saga. ${ }^{31} \mathrm{~A}$ significant part of the contestation is inspired by a political constitutional perspective, which "endorses more classical processes of democratic constitutional organization," while the imperilment of parliamentary sovereignty, the "general hubris of democratically unmandated judicial bodies, and the force of international legal norms is contested." 32

Recently, also in the East-Central European context, legal constitutionalism has become openly criticized and this critique has become the basis of constitutional counter projects. These projects consist in particular in a conservative, nationalist reaction to the domination of the legal-constitutional paradigm in the democratic transformation process since 1989-which in important ways already emerged before the annus mirabilis. As argued by Tamas Györfy, ${ }^{33}$ it was after Fidesz came to power in Hungary in 2010 that Hungarian right-wing intellectuals discovered the theory of political constitutionalism. One instance of this can be found in work by Istvan Stumpf, a Constitutional Court judge appointed by Fidesz. He argues that the "Constitutional Court was the flagship of legal constitutionalism in Hungary" 34 and raised the question whether " 25 years after the change of system, it is time to cut back some of the competences of the Constitutional Court that has gained too much power," as the "Court limits the functioning of the most important representative of people's sovereignty." 35 Stumpf describes views in Hungary that criticize the tendency of "European politics of turning political matters [in] to legal problems" and of an "extreme dominance of human rights logic and the downright limitation of the majority principle' as a version of 'political constitutionalism." 36 With the Hungarian Basic Law (2011), the "activism of the Constitutional Court has been replaced by the activism... based on supermajority and the supremacy of parliament." ${ }^{37}$ In contrast to more

\footnotetext{
${ }^{28}$ Jeremy Waldron, Constitutionalism-A Skeptical View 23 (2010), http://scholarship.law.georgetown.edu/hartlecture/4.

${ }^{29} I d$. at 11 (emphasis in original).

${ }^{30} I d$. at 20.

${ }^{31}$ Christopher Thornhill, A Tale of Two Constitutions. Whose Legitimacy? Whose Crisis?, in BreXIT. SOCIOLOGICAL RESPONSES (William Outhwaite ed.,2017).

${ }^{32}$ Christopher Thornhill, The Mutation of International Law in Contemporary Constitutions: Thinking Sociologically About Political Constitutionalism, 79 MoD. L. REV. 207 (2016).

${ }^{33}$ Győrfi, supra note 7, at 26; see also AgnieszKa BieŃ-KaCAŁA ET AL. EDS., Liberal Constitutionalism-BetweEN INDIVIDUAL AND COLLECTIVE INTERESTS (2017).

${ }^{34}$ István Stumpf, Rule of Law, Division of Powers, Constitutionalism, 55 ACTA JURIDICA HungariCA 299, 302 (2014).

${ }^{35} \mathrm{Id}$.

${ }^{36} I d$. at 309.

${ }^{37} I d$. at 310.
} 
radical, populist positions on super-majoritarian dominance, Stumpf however warns that "[i]f we sacrifice rule of law values and constitutional stability on the alter of political interests, the whole society will have to pay a great price for it." 38 And more recently, Stumpf has argued that:

Constitutional courts in situations of democratic crisis should exercise their competences to their limits to protect the constitutional foundations of the state such as the separation of the branches of government, in particular, the independence of the judiciary, and all those political rights and democratic institutions (freedom of speech, freedom of information, fair electoral system, etc.) which enable the political system to self-correct in a democratic way (e.g. at the following elections). However, the constitutional courts should be careful not to elevate themselves above the constitution and the valid rules governing their competences and procedures - whatever valid cause they claim to defend -, because overstepping the limits would be contrary to the rule of law and detrimental to the culture of the rule of law and democracy (which may potentially backfire at a later point in time). Moreover, judicial activism that violates the competences of other branches of government can serve as a means of direct (and willful) encroachment upon the democratic process. ${ }^{39}$

\section{Communitarian constitutionalism}

The political constitutionalist critique on legal constitutionalism has thus some elective affinity with important political counter-projects - such as Brexit and the populist regimes in East-Central Europe. The key thrust is an endorsement of the re-strengthening of domestic majoritarian, parliamentary politics. In these political projects, the political critique on legal-constitutionalism is in many instances - even if not necessarily so-paralleled by, or combined with, a second critique that is grounded in communitarian views of constitutional democracy. The communitarian critique is equally aimed against a radical-universalist or freestanding view of legal constitutionalism, but puts the emphasis less on democratic majorities and procedures, and more on the historical and cultural bases of constitutional orders. A crucial dimension is the idea of constitutional identity. ${ }^{40}$

A key tension that the communitarian constitutional view invokes is that between universalism and particularism, or between universally valid norms and local moral understandings. What characterizes the communitarian critique and its basis in a communitarian and sometimes outspokenly illiberal understanding of constitutionalism, is the perception of a common enemy in liberal constitutionalism, and a critique of both the meta-liberal value of normative individualism and its understanding of the neutral state. Illiberal constitutionalism, in contrast, emphasizes community interests and the active promotion of a particular vision of communal life. If legal constitutionalism emphasizes a court-centric rights-based constitutionalis,' distinctive nationalpopulist projects invoke a contrasting vision of individuals embedded in and owing allegiance to a given community and endorses an understanding of constitutionalism as a means to protect a distinct community, its ethos, and its traditions. A communitarian view understands the individual as a socially embedded self and the community as highly important in forming the individual. In this view, courts are playing a "secondary rather than counterbalancing role" in that a political view of constitutionalism is seen as corresponding best to a community-preserving project. $^{41}$

\footnotetext{
${ }^{38} \mathrm{Id}$. at 316.

${ }^{39}$ István Stumpf, Separation of Powers and the Politics of Constitutional Reforms, Including Judicial Independence 11 CoNsT. L. REV. 3, 20 (2017), https://iliauni.edu.ge/uploads/other/44/44098.pdf.

${ }^{40}$ The latter dimension, in close relation with a distinctive understanding of the idea of constitutional pluralism, is exactly what is strongly decried by legal constitutionalists as an "inherently dangerous" concept. See Kelemen \& Pech, supra note 10.

${ }^{41}$ Li-Ann Thio, Constitutionalism in Illiberal Polities, in The OxFord Handbook OF Comparative Constitutional LaW 133 (Michael Rosenfeld \& András Sajó eds., 2012).
} 
The communitarian conception of constitutionalism-or in its extreme variantconstitutional nationalism, ${ }^{42}$ is hence grounded in an ethic of identity in that the constitution is understood as a "constitutional and legal structure that privileges the members of one ethnically defined nation over other residents in a particular state." ${ }^{33}$ Rather than prioritizing individual rights and the individual subject as the focus of such rights, the emphasis is on the safeguarding of political sovereignty as embodied by a specific national group. ${ }^{44}$ Or, in more distinct communitarian terms-i.e. regarding an ethic of identity and the communitarian quest for selfexploration and definition of the common good-communitarian constitutionalism "grants a foundational importance to the communal identity and the historical values of the community." 45 The basic ethic of communitarianism is on what people have in common or what unites them, or what ought to unite them-in short, their commonality. ${ }^{46}$ In this regard, the center of gravity in communitarian constitutionalism is on the community, while the state's role is first of all to facilitate, coordinate, and protect the community's outlook and its enduring commonality. ${ }^{47}$

Such communitarian and ethno-nationalist approaches to constitutionalism are particularly evident in the counter-constitutional projects of PiS in Poland and Fidesz in Hungary. These projects have a long pedigree, and the communitarian/nationalist critique of legal constitutionalism has been part and parcel of constitutional politics right from the start of the post-1989 political transformation processes in the region. A clear instance of the early prominence of constitutional nationalism in the region is the post-1989 constitution-making process in Romania, which could in many ways be seen as a clear-but largely unacknowledged-precursor to the current populist backlash in Hungary and Poland. This can be seen in the emphasis of the early post-communist regime, led by Ion Iliescu, on constitutional nationalism, a distrust of international institutions, an invocation of the ordinary people as its constituency, and extreme majoritarian politics. ${ }^{48}$

Communitarian and nationalist constitutional approaches are, however, not confined to EastCentral Europe. A clear case in point, in a distinctive secularist fashion, is the French Front National and its crusade against "communautarisme" (sic), or the co-habitation of different ethno-religious communities within the secular French Republic. Le Pen, the leader and presidential candidate of the Front National, opened her program for the 2017 presidential campaign by stating as key objective " $\mathrm{t}$ ]o regain our freedom and control over our destiny by restoring the sovereignty of the French people." 49 The program contained various calls for constitutional reform, including the following proposals:

The defence of national identity, [and] the values and traditions of French civilization. To inscribe into the Constitution, the defence and the promotion of our historical and cultural patrimony. ... The promotion of secularism and the fight against communitarianism. To inscribe into the Constitution the principle: 'The Republic does not recognize any [ethnic, religious] community.' Restore secularism everywhere, extend it to the entire public sphere, and inscribe it into Labour Law. ${ }^{50}$

\footnotetext{
${ }^{42}$ See Robert Hayden, Constitutional Nationalism in the Formerly Yugoslav Republics, 51 SLAVIC Rev. 654 (1992).

${ }^{43} I d$. at 655 .

${ }^{44} \mathrm{Id}$. at 656.

${ }^{45}$ Camil Ungureanu, The European Constitution-Making and the Question of Religion 3 (EUI Working Papers SPS, 2007/01, 2007).

${ }^{46}$ Winfried Brugger, Communitarianism as the Social and Legal Theory Behind the German Constitution, 2 INT'L J. CONST. L. 431,433 (2003).

${ }^{47} I d$. at 435.

${ }^{48}$ See Paul Blokker, Multiple Democracies in Europe (Routledge 2010); Paul Blokker, The Romanian Constitution and Civic Engagement, 11 ICL J. 437 (2017); Silvia Suteu, The Multinational State That Wasn't: The Constitutional Definition of Romania as a National State, 11 ICL J.: 413 (2017).

${ }^{49}$ Marine Le Pen, '144 engagements présidentiels', 3 (2017), https://rassemblementnational.fr/pdf/144-engagements.pdf.

${ }^{50} I d$. at 15 .
} 


\section{Democratic constitutionalism}

A third-and in important ways distinctly radical—critique of legal constitutionalism is that formulated in different manifestations of what could be called 'democratic constitutionalism,' in which critical, radical-democratic, bottom-up, and agonistic dimensions are at the forefront. The argument of democratic constitutionalism against the dominance of legal constitutionalism is that the latter is deficient in terms of its democratic nature. In Joel Colon-Rios' version of weak constitutionalism, it "rests on the idea that ordinary citizens should be allowed, to the extent to which it is practically possible, to propose, deliberate, and decide on important constitutional transformations through the most participatory methods possible." ${ }^{\prime 1}$

The thrust of democratic constitutionalism is against a one-sided understanding of constitutional democracy, in order and stability, and perceives as the main problem in contemporary constitutionalism its depoliticizing/juridifying tendencies. Democratic constitutionalism understands modern constitutional orders as having urgent problems with democratic legitimacy, in that the legalistic orderly dimension overshadows the democratic, participatory dimension of constitutions. This is particularly evident on the post-national level, where global juridification reproduces some of the features of modern constitutionalism, but at the same time leaves out the democratic dimension of "democratic deliberation of the humans who are subject to [global constitutional regimes],"52 while confining the constituent dimension to a restricted group.

Democratic constitutionalism consists of a critical, normative suggestion of how to radically rebalance the legal and democratic dimensions in the contemporary situation in favor of the democratic-participatory dimension. In this, democratic constitutionalists stress a multiplicity of sites where citizens can engage in democratic practice. ${ }^{53}$ In its emphasis on a multiplicity of relevant sites of democratic practice, democratic constitutionalism has an outspoken agonistic ring, and goes in this beyond the idea of re-politicization through a return to parliamentary supremacy-as in political constitutionalism. What is significant is that democratic constitutionalism invokes both practices of democratic governance or day-to-day democratic politics and the level of fundamental law or the foundations of existing constitutional orders. ${ }^{54}$ A radical democratic view of constitutional democracy claims that democracy would need to entail a more direct and substantive participation of citizens in the democratic process, including constitutional or meta-politics that aims at transforming existing institutions. ${ }^{55}$

For democratic constitutionalism, the nature of the constitution itself is understood in a radically different way from legal constitutionalism. Whereas legal constitutionalism mostly understands:

Constitution making as an "act of completion," the constitution as a final settlement or social contract in which basic political definitions, principles, and processes are agreed, as is a commitment to abide by them, democratic constitutionalism entails a conversation, conducted by all concerned, open to new entrants and new issues, seeking a workable formula that will be sustainable rather than assuredly stable. ${ }^{56}$

Democratic constitutionalism endorses a more open democratic settlement which aims at the "extension of democratic process to include, free, open, and responsive discussion of the

\footnotetext{
${ }^{51}$ J. Colon-Rios, The Three Waves of the Constitutionalism-Democracy Debate in The United States: And an Invitation to Return to the First, 1 Victoria University of Wellington Legal Research Papers VUWLRP 23/2011: 3.

${ }^{52}$ James Tully, Public Philosophy in a New Key 101 (Cambridge University Press 2008).

${ }^{53} I d$. at 98 .

${ }^{54}$ In the terms of Joel Colon-Rios, The Second Dimension of Democracy: The People and Their Constitution, 2 BALTIC J. L. \& POL. 1 (2009).

${ }^{55} \mathrm{Id}$.

${ }^{56}$ V. Hart, 'Democratic Constitution Making', Special Report, U.S. INST. FOR PEACE 2-3, http://www.usip.org.
} 
constitutional settlement," while the latter provides the framework under which "diverse and disagreeing groups can live, while continuing to engage in a freely accessible debate about that settlement itself." 57 In democratic constitutionalism, the democratic dimension of constitutional democratic legitimation clearly has the overhand, even if the constitutional ordering type of legitimacy is not abandoned.

Democratic constitutionalism is clearly not unrelated to theories of radical, agonistic democracy and recent calls for a left populism, which agitate against technocratic, neoliberal forms of rule or post-politics, and endorse a re-politicization in order to recover and deepen democracy. ${ }^{58}$ A crucial aspect of the democratic-constitutional narrative is its relation to constituent power and the emphasis on the human capacity of creation ${ }^{59}$ rather than that of closed, foundational norms and technocratic institutions. Clearly, democratic constitutionalists are not in favor of the reduction of the exercise of constituent power to some original constitutional moment, but rather endorse the possibility of constituent power to re-emerge from time to time within the constitutional order. ${ }^{60}$ This is clearly against the legal-constitutional emphasis on permanence and foundational norms, to be protected by higher judicial institutions.

Empirical manifestations of a democratic-constitutional perspective have been observed both in Latin America, ${ }^{61}$ where populists in power have frequently promoted citizen involvement in participatory democracy-not least in the form of constituent assemblies. In Europe, distinctive constitutional claims by, for instance, the Spanish political movement Podemos indicate the defense of a generally liberal view of constitutionalism and human rights, but also point to an attempt to open constitutional politics to civic input and to extent human rights to marginalized groups. ${ }^{62}$ As we will see extensively below, also on the transnational level, in emerging transnational movements with populist characteristics democratic constitutionalism plays a significant role.

To sum up, we have seen that legal constitutionalism is confronted with competing constitutional visions and narratives, which criticize its depoliticizing tendencies, its individualist and abstract, universalist nature, its lack of acknowledgement of conflicting views, and dearth of possibilities for civic engagement. I have also indicated that each and every competing constitutional narrative shows affinity with specific manifestations of populism. Let us now turn to a pluralistic approach to populist constitutionalism.

\section{B. Varieties of populist constitutionalism}

The relation between populism and constitutionalism cannot be reduced to a purely antithetical one. This is due to the various available positions on, and political projects of, constitutionalismas briefly discussed above. But populism itself equally needs to be approached as an essentially contestable concept. The variety of manifestations of populism is, however, frequently overlooked in scholarly debates, where the antithetical interpretation dominates This means that populism is by definition equated with illiberal, ethno-national, and tendentially authoritarian ideas

\footnotetext{
${ }^{57} \mathrm{Id}$ at 3.

${ }^{58}$ Chantal Mouffe, For a Left Populism 11-12 (2018).

${ }^{59}$ Mark Wenman, Agonistic Democracy: Constituent Power in the Era of Globalisation 7 (Cambridge University Press 2013).

${ }^{60} \mathrm{Cf}$. Joel Colón-Ríos, Weak Constitutionalism: Democratic Legitimacy and the Question of Constituent POWER (Routledge Research in Constitutional Law 2012).

${ }^{61}$ Id. ; Joel Colón-Ríos, Constitution Making and Constituent Power, in Comparative Constitutional LaW IN Latin AMERICA 57 (Rosalind Dixon \& Tom Ginsburg eds., 2017).

${ }^{62}$ Kate Nash, Politicising Human Rights in Europe: Challenges to Legal Constitutionalism From the Left and the Right, 20 INT'L J. OF HUM. RTS. 1295 (2016).
} 
and practice. As Rob Howse has aptly remarked, ${ }^{63}$ much of this stems from a relatively narrow view of liberal, representative democracy, which anti-populists intend to defend against what is perceived as liberal democracy's most pressing challenge: populism. As also Michael Freeden has argued, the equation of "populism with democratic illiberalism requires further elaboration," not least because both liberalism and populism come in many forms and shapes. ${ }^{64}$ Freeden in this regard normalizes populism in that he considers it "a slippery concept to define, attracting a range of cultural and geopolitical connotations that overlap only with difficulty," a condition which can, however, be seen as pertaining to "other ideological variants" too. ${ }^{65}$ Indeed, the search for clear-cut definitions of the phenomenon of populism - as most prominently in the form of the simplified thin-centered or thin ideology idea — seem to be beside the point and analytically speaking counter-productive.

A starting point should hence be: What are the overlapping as well as differing dimensions to manifestations of populism? And in this context of a discussion of constitutionalism, to what extent do differences matter? As argued in the introduction, the core, overlapping characteristics of populism include: First, a friend-enemy logic in populist political mobilization; second, a critical attitude towards liberal democracy, which according to populists, is inadequate in promoting popular sovereignty; and third, the crucial role of constituent power in populist projects. In terms of differences, I propose-in a non-exhaustive manner-three dimensions: 1) inclusionary versus exclusionary forms of populism; 2) reformist versus revolutionary forms; and 3) national versus transnational manifestations.

\section{Inclusion/exclusion}

Populism is frequently displayed as a politically exclusionary force, as understanding society as divided between the pure people and its enemies, and mobilizing the former as a unitary, collective actor against the latter. The exclusionary tendency of the construction of the people-and the related process of othering - appears to point to a necessary closure of a political community towards those that are defined as external. But this is not necessarily the case. Admittedly, key dimensions of populism are its anti-elitist and anti-establishment positions, and in this populists promote the cause of the underrepresented and marginalized parts of society. But the mobilization of the latter groups and the promotion of their interests does not necessarily lead to an exclusionary approach. Populism in some cases promotes the conquest of existing institutions by popular forces. In this, they attempt to sweep away the political hegemony of the enemies, replace it by the rule of the popular forces, while also obstructing any further political and public participation or influence of these enemies. But other forms of populism, while equally making claims against elites, promote political and material inclusion of previously excluded groups in-reformedexisting institutions, endorsing pluralism, and redistributive justice. As Kate Nash argues in her discussion of populist forces criticizing legal constitutionalism in Europe, distinctive left-wing populist forces such as Podemos use patriotic language identifying the people. The latter is not defined in a closed manner, includes non-national, marginalized groups such as migrants, and calls for amelioration of the political and socio-economic positions of the latter vis-a'-vis those of the privileged. ${ }^{6}$

An exclusionary or inclusionary thrust in populist political forces has potentially great implications for the constitutional projects such forces pursue. While comparative work regarding populism and constitutionalism in Latin America and Europe is scarce, preliminary investigations show that highly important differences exist in terms of inclusionary, participatory and

\footnotetext{
${ }^{63}$ Rob Howse, 'Populism and its enemies', draft paper; $c f$. Jeffrey Isaac, 'Is There Illiberal Democracy? A Problem with no Semantic Solution', Public Seminar, http://www.publicseminar.org/wp-content/uploads/2017/07/Isaac-Jeffrey-Is-ThereIlliberal-Democracy-Public-Seminar.pdf.

${ }^{64}$ Michael Freeden, After the Brexit Referendum: Revisiting Populism as an Ideology, 22 J. POL. IDEOLOGIES 1, 2 (2016).

${ }^{65} \mathrm{Id}$. at 2.

${ }^{66}$ Nash, supra note 62.
} 
bottom-up, democratizing dimensions of constitutional reform in Latin America if compared to the outright majoritarian, nationalist, and conservative projects in East-Central Europe. ${ }^{67}$ The difference could be simplified as between radical democracy and communitarian or conservative understandings of democracy. The particular constitutional instruments used by populist forces change accordingly, with an emphasis on innovative, participatory instruments-constituent assemblies, referendums, town meetings - in radical-democratic populism, and, in contrast, on constitutional identity, majoritarian-partisan political dominance, restriction of minority rights, and top-down reform in nationalist, conservative forms.

\section{Past versus future}

A second diversifying dimension to populism is that relating to conservatism and revolutionism, or backwards-looking and forward-looking projects of populism. Populist movements ought to be understood as reactionary, in the specific sense of reacting to a specific political order or a distinctive status quo. In other words, a hegemony of some sorts is criticized in the name of popular sovereignty. This brings back into the discussion an insight that was frequently made in the early 2000s: That populism is intrinsic to liberal democracy. The populist reaction is hence against the liberal-democratic status quo and decries its detrimental effects on popular sovereignty and the interests of the ordinary people. The critical dimension is clearly a negative dimension, arguing against the current political and institutional constellation. This critical approach towards liberaldemocracy - while at the same time claiming to remain within the democratic endeavor isis what distinguishes populism across the board.

It is on the positive (constructive) dimension that populist projects start to differ importantly. The invocation of popular sovereignty is importantly about the claim to retrieve a lost promisethat is, of the rule of the people. And hence, populists seek to retrieve something that according to them existed in the past, or that has been part of a societal project but was then corrupted. A crucial distinction is subsequently between two types of populism. The first is one that perceives the liberal-democratic project as ultimately deeply flawed and hence in need of being replaced by a radically different understanding of democracy-i.e., emphasizing collective, cultural, and historical dimensions against liberal democracy's individualism, deeply skeptical of the ontological presuppositions of the liberal-individual idea. The second is one that accepts some of the fundamentals of liberal-democratic society - the individual, related human rights, popular self-government-but perceives the current liberal-democratic as greatly distorted in realizing such ideals.

\section{National and transnational populism}

The larger part of the literature tends to equate the populist quest for the people as one of a necessarily national character. This is reflected in a recent volume's title is "National populism. The revolt against liberal democracy," 68 while it is an intrinsic, definitional part of much theorizing on the subject. ${ }^{69}$ This is not least because of the taken-for-granted linkage between popular sovereignty and liberal democracy. Conceptually and historically there appears much to be going for such a form methodological nationalism, as the people has predominantly been imagined to be forming a national political community.

\footnotetext{
${ }^{67}$ Paul Blokker, Populism and constitutional change, in The Routledge Handbook on Comparative Constitutional Change (Xenophon Contiades \& Alkmene Fotiadou eds., forthcoming 2018).

${ }^{68}$ Roger Eatwell \& Matthew Goodwin, National Populism: The Revolt Against Liberal Democracy (2018).

${ }^{69} \mathrm{Cf}$. Oklopcic fc.

Zoran Oklopcic, Imagined ideologies: Populist Incarnations, Liberalist Projections, and the Horizons of Constitutionalism, GERMAN L. J. (forthcoming)
} 
An important part of the political manifestations of populism can, admittedly, be grouped under the notion of national populism. But it also needs to be recognized that an equation of populism with the national political community may reduce our capacity to understand the phenomenon. As amongst others Rogers Brubaker has pointed out, the people comes in different guises-plebs, demos, nation, or ethnos ${ }^{70}$. While the ethno-national definition of the people speaks for a methodological-nationalist analytical lens, other meanings of the people are much less moored to the imagination of a national political community. Brubakers further refers to the vertical and horizontal dimensions to constructing, two dimensions that provide additional support for a more complex view of the populist people. ${ }^{71}$ The vertical dimension relates to the typically populist elite-ordinary people or rulers-ruled distinction, while the horizontal dimension stresses insiders and outsiders.

What emerges from such observations is that the people can be constructed in very different ways, and its specific relations to elites and outsiders depends on the specific populist project one looks at. National populism may develop an international dimension in terms of the coordination between national populist movement for a common purpose-as currently is occurring with regard to the elections of the European Parliament - in the lead-up to which populist forces mobilize in order to conquer the EU institutions. ${ }^{72}$ A different, transnational form transcends international collaboration in that it constructs the people in truly transnational terms: As a post-national, marginalized subject, mobilized against exploitative and hegemonic transnational elites. $^{73}$

What is striking is both the difficulty and fragility of the transnational populist enterprise-in constructing its people-but equally its necessity-from a democratic-participatory perspective. The latter remark reflects the observation that national, liberal-representative democracy is in a dire state. ${ }^{74}$ The current predicament of liberal democracy is due to a whole range of complex and intertwining factors, which prominently includes the decreased potential of popular sovereignty. One factor in the reduced political decision-making power of individuals and governments is the emergence of distant but powerful international and transnational actors and phenomena-such as transnational constitutional regimes. Transnational populism lifts the struggle over popular sovereignty to the transnational level, where the real action is.

\section{Transnational populism and constituent politics}

Transnational populism appears as counter-intuitive and contradictory, in that, as mentioned above, populism is predominantly understood as a political project around a nationally bounded people. The populist friend-enemy logic frequently evolves around the defense of a nationally imagined people against internal and foreign enemies. The distinctive populist logic can however equally be observed in transnational political projects, in which a transnational people is pitted against a set of transnational enemies-for instance, financial elites, bureaucrats, or powerful states.

Despite limited attention to the phenomenon, transnational populism may prove to be of significant importance; in particular in contexts in which a combination of post-national legal, economic, and political interdependence is now being threatened by reactionary national populisms, as in Europe. As amongst others Markus Patberg has forcefully argued, if the EU wants to avoid disintegration, it needs a "constitutional renewal," not least since the "Europe of governments has

\footnotetext{
${ }^{70} \mathrm{R}$. Brubaker, Why populism?, 46 THEORY AND SOC'Y 357, 359 (2017).

${ }^{71}$ Brubaker, supra note 70 .

${ }^{72} \mathrm{Cf}$. Benjamin Moffitt, Transnational Populism? Representative Claims, Media and the Difficulty of Constructing a Transnational "People", 24 Javnost-The Public 409, 410 (2017); Benjamin De Cleen, Populism and nationalism, in The OXford HANDBOOK OF POPUlism (Cristóbal Rovira Kaltwasser et al. eds., 2018).

${ }^{73}$ Moffitt, supra note 72 , at 411 .

${ }^{74}$ John McCormick, La crisi della democrazia contemporanea e il grido di dolore populista, 30 IRIDE 539 (2017).
} 
exhausted its political credit."75 The EU context is urgent, in that the postwar integration project, deeply grounded in legal and constitutional structures-as visible in a distinctive legalconstitutional structure with a strong apex court and primacy of EU law-is forcefully challenged by national populists forces. This is evident in various instances: In Brexit, in the counterconstitutional projects of the Hungarian and Polish governments, as well as in countries such as Italy, in which the populist coalition pursues a decisively 'sovereigntist' project, with a distinctively populist approach to public law.

Transnational populism of a left-wing version stands out in its opposition to such nationalist projects. It is of importance-in that it does not return to the national imagination of democracyas the national populists and many others do, but rather pursues a largely transnational imaginary. In this, it could be argued, it provides a more comprehensive answer to the contemporary predicament of liberal democracy. This predicament, as John McCormick has argued, is increasingly one of failing electoral functions, plutocratic tendencies, and lack of accountability. ${ }^{76}$ The focus below will be on one significant manifestation of transnational populism in Europe, the Democracy in Europe Movement, DiEM25.

\section{Transnational populism: what makes DiEM25 populist?}

The European movement DiEM-25, initiated by former Greek Finance minister Yanis Varoufakis in 2016, purports to be a transnational political movement, and boasts some 79,000 members worldwide (February 2019). ${ }^{77}$ The two key purposes of DiEM25 are to stabilize the reeling European economy_proposing a New Deal for Europe-and to democratize Europe, in particular by means of the establishment of a citizens-based, "new Constitutional Assembly" to "draft a Democratic European Constitution."78

But to what extent is this transnational political movement a populist endeavor? I propose to start the analysis with the three basic ingredients of populism mentioned in the introduction: Invocation of a friend/enemy distinction, a critical stance towards liberal democracy and legal constitutionalism, and recourse to constituent politics. I will discuss the DiEM25 project in this light, while equally referring to the three dimensions of variety discussed above: Inclusion/ exclusion; past versus future; national versus transnational.

The friend/enemy distinction - or rather people versus the elite position — is relatively diffused in the DiEM25-project. As DiEM25 states in its founding manifesto:

We, the peoples of Europe, have a duty to regain control over our Europe from unaccountable "technocrats" complicit politicians and shadowy institutions. We come from every part of the continent and are united by different cultures, languages, accents, political party affiliations, ideologies, skin colours, gender identities, faiths and conceptions of the good society. We are forming DiEM25 intent on moving from a Europe of "We the Governments," and "We the Technocrats," to a Europe of "We, the peoples of Europe."

DiEM25 mobilizes European citizens in order to contest European technocrats and corrupt politicians while at the same time taking on national populists or authoritarian movements. In its 2016 manifesto, various of its enemies are singled out, inter alia "the Brussels bureaucracy,"

\footnotetext{
${ }^{75}$ M. Patberg, Challenging the Masters of the Treaties: Emerging Narratives of Constituent Power in the European Union, 7 Global Const. 263, 263 (2018).

${ }^{76}$ McCormick, supra note 74 , at 539.

${ }^{77}$ See https://internal.diem25.org/members?locale=en (accessed on 14/02/2019).

${ }^{78}$ DiEM25, A Manifesto for Democratising Europe (2016), https://diem25.org/manifesto-long/; Panos Panayotu, Towards a Transnational Populism: A Chance for European Democracy (?) The Case of DiEM25 14 (POPULISMUS 5, January 2017).

${ }^{79} I d$. at 7 (emphasis added).
} 
"the Troika," "the powerful Eurogroup," "the bailed out bankers, fund managers and resurgent oligarchies." 80

The transnational people constructed by DiEM 25 consists in a broad and relatively open-ended construction of a transnational people of peoples. Varoufakis in the launching event of DiEM25 in February 2016 articulated the people in a pluralist sense, and as including "[p]eople from the north, the south, the east, the west, the core, the peripheries, Slavic countries, catholic countries, protestant countries" as well as "a broad coalition of democrats, radical democrats, left-wing democrats, social democrats, liberal democrats." ${ }^{81}$ In this open-ended approach towards the construction a European people, one clearly detects an inclusionary rather than a strongly exclusionary logic as found in many right-wing populisms. The left-wing populism of DiEM-25-with its emphasis on a positive image of the ordinary people, the inclusion of the marginalized and disempowered, and widespread popular political participation-has some affinity with the participatory claims and constituent politics of Latin American left-wing populism. ${ }^{82}$

The transnational nature of the project equally comes through in a strong anti-nationalist standpoint. In its New Deal for Europe, DiEM25 denounces the "Nationalist International," which promises to "restore hope through taller walls that control the movement of people and goods." 83 DiEM25 does not deny the national altogether, but rather calls for a democratic strengthening of sovereignty on both the national and transnational levels. In its mobilization and construction of a transnational people, DiEM25 follows a populist logic to the extent that it promotes a form of hyper-representation, in constructing a unitary people out of highly disparate parts of (European) society, and pitting it against those forces that betray the people's interests, that is, the "Nationalist International and Europe's culpable establishment." 84

\section{Critique of liberal democracy and legal constitutionalism}

In the view of DiEM25, the EU needs a foundational revision of the European treaties and the establishment of a European democratic federation. In contrast to anti-establishment views on the populist right, DiEM25 does not take a deeply anti-liberal attitude. ${ }^{85}$ In general, DiEM25 does not appear to engage in a comprehensive critique of the liberal rule of law or European integration-through-law, as is, in contrast, outspoken East-Central European populists such as PiS in Poland and Fidesz in Hungary, and in a different manner in the critique on (neo-)liberalism in Latin American populisms. ${ }^{86}$ The right-wing populist anti-liberal stance contests legal, universalist constitutionalism because of undue judicial activism by apex courts-intruding into the sovereign prerogatives of the political majority - an unwarranted claim to neutrality of the law, and an illegitimate interference of external judicial norms and powers into domestic affairs ${ }^{87}$ In the case of the transnational populism of DiEM25, this form of Schmittian critique is less visible; the few references to such a critique include a denunciation of European elites that uphold the "sanctity of the existing 'rules,"” which underpin what according to Varoufakis is the

\footnotetext{
${ }^{80} I d$.

${ }^{81}$ Cf. Alice Masoni, Is Transnational Populism Possible?-The Case of DiEM25, (2018) (Thesis Vrije Universiteit Brussel).

${ }^{82}$ Panos Panayotu, Towards a Transnational Populism: A Chance for European Democracy (?) The case of DiEM25 14 (POPULISMUS 5, January 2017).

${ }^{83}$ DiEM25, European New Deal 5 (2018), https://diem25.org/diem25-unveils-its-european-new-deal-an-economic-agendafor-european-recovery/.

${ }^{84}$ DiEM25, supra note 78, at 7; cf. Panayotu, supra note 82, at 11.

${ }^{85}$ In strong contrast with the typically anti-liberal view and legal resentment of right-wing populists. See Blokker, supra note 67.

${ }^{86}$ Javier Couso, Law, Rights and Social Change in Latin America: Competing Models of Constitutionalism in an Era of Uncertainty, http://www.derecho.uba.ar/academica/posgrados/2012_javier-couso.pdf.

${ }^{87}$ Paul Blokker, Populism as a Constitutional Project, INT'L J. ConST. L. (forthcoming, 17: 2, 2019).
} 
"discretionary, autocratic power" of the EU. ${ }^{88}$ It equally comes through in a critique of a legalistic, post-political idea of European law, in which the idea of sovereignty is seen as passé. ${ }^{99}$

In general, however, the transnational populists claim to uphold a largely liberal view of constitutional democracy, but, as we will see, with strong, critical emphasis on democraticconstitutional, rather than legal-constitutional, components. There is in this a past-oriented dimension-coming through in calls for a return to an EU based on the "basic principles of a constitutional democracy" - as the "Western European appreciation of the founding principles of liberal democracy has been depleted." $"$ This is particularly so due to the emergence of a form of despotism or unchecked and intransparent wielding of sovereign power by dominant member states since the economic crisis of 2008. The upholding of a liberal order also comes through in DiEM25's calls for "constructive disobedience," which is about the breaking of the law "in particular instances to scandalize and ultimately remedy legitimacy deficits of an overall legitimate political system." ${ }^{91}$ But the future-oriented focus of DiEM25 appears as more prominent-as in the critique on the EU legal system for its marginalization or outright exclusion of the popular voice the lack of a sovereign parliament, the rule of technocrats, and in claims for a democratic deepening of integration.

The transnational populists hence invoke the basic principles of liberal democracy but equally follow a critical, democratic-constitutional approach by invoking constituent politics as their main project (see below). As one DiEM25 member argues, "[b]y making the member-states the Masters of the Treaties, the people are explicitly cut out from the pouvoir constituent, having only an indirect influence over the treaties' content." ${ }^{22}$ The most prominent critique is that the EU consists of a technocratically driven, market fundamentalist project, where "all decisions are made beyond the sight and control of citizens, and our enslavement to our economic conditions becomes an immutable fact of life." 93 As DiEM25 states in its statement European Constituent Assembly, the "EU is a complex institutional framework which remains largely obscure for the people of Europe and where technocrats take decisions behind closed doors to serve the national elites and corporate interests." 94 The EU treaties that provide the basis for European integration "give a platform for politics to take place above citizen-led democratic politics and they justify the lack of democratic control over the processes and institutions of the union." 95

\section{Constituent project}

The DiEM25-project is not predominantly driven by the call for a (re-)strengthening of the legalconstitutional dimensions of the EU to contrast the emergence of "executive federalism" $" 96$ nor by an endorsement of a political-constitutional correction of the current EU legal order. The latter would entail a decisive strengthening of the parliamentary dimensions of decision-making in

\footnotetext{
${ }^{88}$ Yanis Varoufakis, Can Europe Escape its Crisis Without Turning into an Iron Cage, https://www.yanisvaroufakis.eu/2014/ 09/07/can-europe-escape-its-crisis-without-turning-into-an-iron-cage/.

${ }^{89} \mathrm{Id}$.

${ }^{90} \mathrm{Id}$.

${ }^{91}$ DiEM25, A Guide to "Constructive Disobedience, https://diem25.org/constructive-disobedience/; Markus Patberg, Destituent Power in the European Union: On the Limits of a Negativistic Logic of Constitutional Politics, J. INT'L POL. THEORY 1, 8 (2018).

${ }^{92}$ Sam Hufton, A Treatise on European Government: On the International and the Problems of the Treaties, OPENDEMOCRACY (2017), https://www.opendemocracy.net/sam-hufton/treatise-on-european-government-international. ${ }^{93} \mathrm{Id}$.

${ }^{94}$ DiEM25, European Constituent Assembly 3 (2017), https://diem25.org/wp-content/uploads/2018/04/ DiEM25_Constituent_Assembly_draft.pdf; Markus Patberg, Destituent Power in the European Union: On the Limits of a Negativistic Logic of Constitutional Politics, J. INT'L Pol. Theory 1 (2018).

${ }^{95}$ Hufton, supra note 92.

${ }^{96}$ Jürgen Habermas, The Crisis of the European Union: A Response (Polity 2013).
} 
the EU. ${ }^{97}$ What makes DiEM25 stand out is its strong emphasis on a democratic-constitutional approach, which puts popular sovereignty and citizen participation at the center of its project.

In its draft manuscript 'European Constituent Assembly', put forward in April 2018, DiEM25 states that it will "show the corrupt elites that there is a European demos, and put democracy at the center of the European project." 98 The mission is indeed to "take power back from the elites." 99 DiEM25 employs both a strategy of destituent power, ${ }^{100}$ in particular by endorsing "constructive disobedience," 101 and a strategy of constituent power, in its call for a constituent assembly. DiEM25 claims that "Europe must abandon the already defunct phase of treaties towards a constitutional momentum: A common approach with a pan-European perspective is necessary." The project is to draw up a new Constitution for Europe:

A constitutional text would serve as a fundament that defines a new sovereign political entity, a new legitimate community of equals, a framework from which law and rights stem. The Constitution, elaborated by the peoples of Europe, would become the source of legitimacy and sovereignty. It will be the beginning of a new age: [T]he age of "We, the People of Europe!"102

DiEM25 decries the 'incompetent authoritarianism' that has come to define the EU in its austerity policy, and which increasingly puts into relief the inadequacy of top-down, legalistic understanding of European integration:

The intergovernmental and technocratic system of the EU increasingly frustrates any meaningful space for the expression of European citizenship. For as much as the Parliament has gained powers of co-decision, decision-making has moved to informal groups like the Eurogroup, intergovernmental agreements outside of the Community method (such as the Fiscal Compact or the scandalous EU-Turkey agreement), and into secretive 'trialogue' negotiations. The structure of the Parliament itself prevents the emergence of real transnational parties. By consequence, European citizens are deprived of political agency at precisely the time when they demand it and need it the most. ${ }^{103}$

The constituent assembly to be formed to counter the lack of citizen political agency is to be set up in such a way that the "whole of European society has a voice," 104 which in practice is to mean that it will be composed in the following way: " $25 \%$ will be randomly drawn among the entire body of the European citizens; $25 \%$ will be directly elected by the citizens via transnational lists; $25 \%$ will represent the member states, while the final $25 \%$ will represent territories and municipalities." 105

The DiEM25 constituent project is clearly aimed against the existing status quo. It starts from the assumption that an executive-driven, treaty-based EU is flawed. It is, in this, however, neither

\footnotetext{
${ }^{97}$ This is clearly at the heart of another project recently launched, the Manifesto of Thomas Piketty. See GUARDIAN (Dec. 9, 2018), https://www.theguardian.com/commentisfree/2018/dec/09/manifesto-divided-europe-inequality-europeans.

${ }^{98}$ DiEM25, supra note 9492 , at 3.

${ }^{99}$ Id at 3.

${ }^{100}$ Markus Patberg, Destituent Power in the European Union: On the Limits of a Negativistic Logic of Constitutional Politics, J. INT'L POL. THEORY 1 (2018).

${ }^{101}$ DiEM25, supra note 91.

${ }^{102}$ DiEM25, supra note 78, at 4.

${ }^{103}$ Lorenzo Marsili \& Niccolò Milanese, Time to Elect a European Constituent Assembly (Without Asking Anyone's Permission) (2018), https://www.greeneuropeanjournal.eu/time-to-elect-a-european-constituent-assembly-without-askinganyones-permission/.

${ }^{104}$ DiEM25, supra note 94 , at 5.

${ }^{105} \mathrm{Id}$. at 7 .
} 
of the nostalgic kind, ${ }^{106}$ endorsing a return to the national, democratic past approach-which is promoted in different ways by both some constitutionalist theorists and by national populistsnor of the classical, federalist kind, which endorses the deepening of the existing integration process - examples of the latter are the formula of the Spitzenkandidaten and other rather modest proposals for injecting some form of representative dimension into supranational institutions. DiEM25 is taking a populist-cum-democratic-constitutional approach in endorsing a strong citizen-based component in a constituent process of remaking the EU.

\section{Concluding remarks}

As the argument above shows, the discussion of the relation between populism and constitutionalism cannot be reduced to one of erosion, that is, the first eroding the latter. Even if one insists on the reduction of the constitutional imagination to the legal-constitutional idea and modelcontrary to my argument in this Article-it is evident that not all manifestations of populism can be understood as merely a threat to liberal constitutional democracy. This becomes particularly clear in versions of populism which do not attack legal constitutionalism tout court, but rather criticize constitutional reality for not living up to legal constitutionalism's promises-of legal certainty and transparency, equality, rights protection, and for reducing meaningful ways of exercising popular sovereignty. As shown in the case of DiEM25, the constituent project for the EU claims to be strengthening the constitutional and rule-of-law dimensions of the European project, not least by seeking a public, citizen-driven process of political constitutionalization, which is to fundamentally correct the one-sided, legalistic, executive-driven, post-politics state of affairs in the EU.

The DiEM25-project draws attention to deep intrinsic problems of two main views of the European future: The legalistic utopia, in which constituent power is entirely absorbed by judicial institutions and rights adjudication and the populist utopia or a Europe of the nations, in which constituent power is entirely absorbed by populist majoritarian executives. The Diem 25 proposal is to instill a deep popular-democratic component into constituent politics, in an attempt to mobilize a cross-border European people against both the technocratic and the national-populist imaginations of the European project.

\footnotetext{
${ }^{106}$ Patberg identifies a constituent narrative of a "retrospective or functionalist" nature, in which popular sovereignty is attributed to European integration ex post or is equated with de fact treaty-making by the powers that be. Patberg, supra note 74 , at 265 .
}

Cite this article: Blokker P (2019). Varieties of populist constitutionalism: The transnational dimension. German Law Journal 20, 332-350. https://doi.org/10.1017/glj.2019.19 